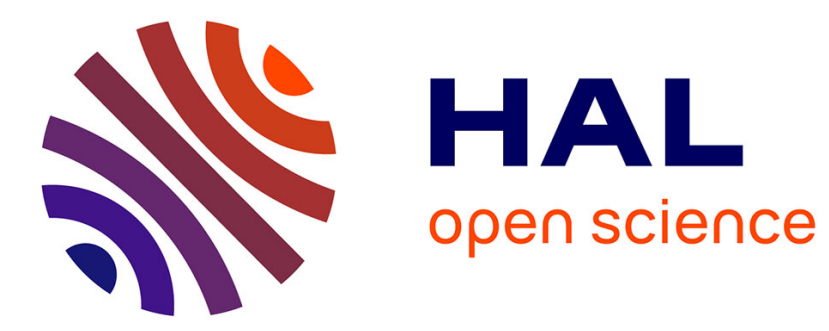

\title{
International security, defence economics and the powers of nations
}

\author{
Ron Smith, Jacques Fontanel
}

\section{To cite this version:}

Ron Smith, Jacques Fontanel. International security, defence economics and the powers of nations. Jacques Fontanel; Manas Chatterji. War, Peace and Security, 6, Emerald, pp.37-51, 2008, Contributions to conflict management, peace economics and development, 978-0-4445-3244-2. 10.1016/S15728323(08)06003-7 . hal-02091131

\section{HAL Id: hal-02091131 https://hal.univ-grenoble-alpes.fr/hal-02091131}

Submitted on 17 Apr 2019

HAL is a multi-disciplinary open access archive for the deposit and dissemination of scientific research documents, whether they are published or not. The documents may come from teaching and research institutions in France or abroad, or from public or private research centers.
L'archive ouverte pluridisciplinaire HAL, est destinée au dépôt et à la diffusion de documents scientifiques de niveau recherche, publiés ou non, émanant des établissements d'enseignement et de recherche français ou étrangers, des laboratoires publics ou privés. 


\title{
INTERNATIONAL SECURITY, DEFENCE ECONOMICS AND THE POWERS OF NATIONS
}

\author{
RON SMITH and JACQUES FONTANEL \\ In War, Peace and Security, \\ Contribution to Conflict Management, Peace Economics and Development \\ Editions Jacques Fontanel et Manas Chatterji \\ Volume 6 \\ Emerald, Bingley (UK),
}

Defence economics is often perceived as series of questions that arise in the intersection between the spheres of strategic policy and the sphere of economy, which occurs at the individual, the national and the systemic levels. Defence economics must study and take account of the realities of strategy, but the models it brings to the party are those of economists.

It is quite impossible to define an optimal security function, because it depends of the perception of the security, of the results (and their distribution) of economic globalization and of the international armaments negotiations.

Security has a large variety of meanings. Individuals are secure if they can have reasonable confidence in their safety and their ability to meet the basic needs. At the individual level, economics emphasises Adam Smith's observation of man's natural propensity to "truck, barter and exchange". But the strategist asks why "truck, barter and exchange" when you can rob, pillage and loot. Then, it is the function of the state to stop people from choosing these last solutions. The law or the social group will ostracise the cheater. However, in some cases, national security is sometimes different of citizen's hopes and of the interests of social categories. Threats to security can come from environmental, economic and strategic forces, such as disease and floods, financial crises, unemployment, or terrorism.

International security must be analyzed as the security of most people in the world, including the danger of a nuclear war, global warming, famines and terrorism. Cooperation within a group has been central to human survival since pre-historic terms. It has to enforce morality or considerations of a long term self interest in reciprocity. There are costs, particularly loss of autonomy, but there are also benefits from interdependence. The growth of information technologies has introduced new threats, including information warfare by terrorist groups or hegemonic policy of a State. What are the incentives that cause nations to work together in their joint interests. Cooperation involves trade-offs.

Today, the development model of USA, European Union and Japan is not compatible with a sustainable development. Then, the military power becomes an important component of the economic negotiations. Again, defence policy lies in the intersection of the spheres of economics which provide the resources that supply defence output and strategy, that provide the demand for it. When economists have to work with defence and security problems, they try to give some replies to three fundamental questions that have guided studies links between the economy and defence policy (Fontanel, 2002): 
- Guns or butter? What are the opportunity costs of military spending on economic development? However, there is an apparent paradox. It is possible to have a large amount of defence expenditure with economic growth and sometimes no good economic results without any military expenditure.

- What is the Bang for the Buck? Considering the military efficiency of arms and strategies, what are the best arms purchase between the same kinds of weapons (such as what choice of tanks or guns) in relation with economic constraints? Nuclear weapons or not?

- What is the optimal level of spending? Given that societies have military as well as civilian goals with relatively limited resources available, what are the allocations of public funds on defence in relation with the uncertainty of particular threats? The long run production system implies some strategies for three to five decennia. It is the main question of the policy of arms race (Fontanel, 2005). The classic question is: "how much is enough?" What is the right share of output to devote to defence?

There is a set of input-output relations, each of these with links to the economic and strategic environments. At the top there is the defence budget. These forces provide military capabilities and the ability to prevail in specified sorts of conflicts. These military capabilities can then be used for defence or deterrence to provide security, measured in terms of the ultimate goals of society. International comparisons are very difficult to produce, because of the military secret and the change rate bias. In the mid 1970s the CIA doubled its estimates of the share of output that the USSR devoted to the military, because they had over-estimated the efficiency of the Soviet defence industry. Although the revision was widely interpreted as indicating that the Soviets were more threatening, in fact it indicated that they were less threatening, only half as efficient.

Much modern defence economics centres on arms races. It is analyzed itself as a dynamic process of interaction and competitive increase of the quantity andlor the quality of armaments by two or several States (or coalition of States). The two equation model of Richardson (1960), with the race driven by political, strategic and economic factors, constitutes the basic model. It introduced the military expenditures of the enemy or the enemies, the economic burden (the effect of fatigability) and the grievances. Theses analyses were clearly false. First, the action-reaction processes are not clearly established and the internal forces seem to be more explicative. Second, they were not able to forecast the crisis of Soviet Union. Third, they give a "security" justification to the increase of military expenditures, emphasizing economic consideration. Forth, they use the implicit hypothesis of the resemblance of the rival States. Five, the technological superiority is not a guarantee of security or of a victory in case of war. How military capabilities translate into security is a matter of grand strategy. At the end of the First World War, France constructed the Maginot Line to protect itself, but the money was used for a defence strategy that was not successful. In principle national powers look at the threats to their security. However, the strategic games are not easy to interpret. Should strategy be offensive or defensive? What is the right balance between capital (more aircraft) and labour (more soldiers)? The Defence Ministry has to make a lot of choices, which usually do not concern the short run, but set the national strategy for decades.

Moreover, industrial and political interests, inter-service rivalry and a variety of bureaucratic forces are often more important. What are the possible threats to the UK or France and how likely are they? The will of a sensible insurance premium 
introduce these main questions: How much is enough and with what armaments and strategies adapted to various threats?

\section{Military Budgets and the Economy}

What are the macroeconomic effects of military budgets on the economy? In financing large wars, the macroeconomic effects are crucial. Currently, decisions about defence budgets probably should be taken in terms of threats and opportunity costs, not only macro-economic effects. Higher military expenditure means other government expenditure is relatively lower, taxes and interest rates are higher, or the budget deficit is higher.

Some peace investment were available in the 1990s with the reductions in military expenditures However, if there is unemployment, higher military expenditure boosts demand and can reduce unemployment. However, the German armament industrialization was part of a process of preparing for war. Military expenditure may reduce investment, perhaps through the crowding out caused by higher interest rates as a result of government deficits. There may be an effect on technical progress. Some get positive effects, some negative, some near zero. Overall the literature has no definite conclusion. We can observe all four combinations of high and low growth and high and low share of military spending in GDP.

- Countries with a high threat so high military expenditure but great growth potential, like South Korea and Taiwan in the 70 s and 80 s, show a high share of military and a high growth rate.

- Countries where a high share of military expenditure did displace productive investment and other factors were unusable to growth, like the Soviet Union, where the share was probably over $20 \%$, show a high share and low growth.

- Countries like post-war Japan and Germany that restricted their military expenditure and could devote it to investment showed low shares and high growth.

- Countries like most of Sub Saharan Africa where shares of military expenditure are low, but so is growth.

\section{Budgets and Forces}

How many forces you get for your budget is the "bang for a buck" issue. It depends on national wage rates, with volunteer forces; the efficiency of the defence industry in building the weapons; the costs of other inputs, fuel, food, etc.; the size of the non-fighting bureaucracy and the efficiency of the expenditure and acquisition process itself. This raises a range of standard defence economics questions about importing-collaborating-producing-exporting; defence industrial strategies; types of procurement process, cost-plus fixed price etc.; the balance between quality and quantity of equipment, etc.

In the product market, there are the issues of where you get your weapons from abroad, collaboratively or at home. What sort of defence industrial strategy you should have? What is the value of arms exports? In technology there has been substantial debate about the value to civilian society of spin-offs from military technology. The important issue is how the military gets the technology it needs to meet its military objectives. However, big commercial producers like Microsoft are also unwilling to provide the guarantees that military customers have traditionally demanded.

\section{Forces and Capabilities}


The transformation of forces to capabilities, the ability to win, depends on all the standard military virtues: training, logistics, leadership, morale, tactics and strategy and because of the vagaries of all these things it can be a very uncertain transformation. Voltaire argued "God Was on the Side of the Big Battalions".

\section{Globalisation}

At the systemic level defence economics concerns the overlap between the global economic environment and global strategic environment. The economic environment is the sphere of trade, globalisation, the price of oil, the future of the dollar, etc; the strategic environment is the sphere of nuclear proliferation, interacting national interests, threats, failed states, etc. Mercantilism/Leninism, which sees strategic conflict as a continuation of economic competition by other means and Manchester liberalism which sees close trading links as inhibiting military conflict, both have their adherents today.

Globalisation is neither new nor inevitable. Marx and Engels, in the Manifesto of the Communist Party explain it"Modern industry has established the world market ... This market has given an immense development to commerce, to navigation to communication". The $19^{\text {th }}$ century flows of labour were much larger proportionately than the immigration we worry about today. On some measures we have only recently passed the degree of globalisation observed in 1913. That also makes it clear that globalisation is also not inevitable, it was ended by World War I and the inter-war depression. It might be ended again. Because more advanced weapons give a potential advantage to adversaries, restriction on their transfer has been common

\section{The Power of Nation States}

Both in the economic sphere and in the strategic sphere there is a perception that the power of the nation state to act is reduced, that it is more constrained and less effective at meeting its national goals. This should not be exaggerated. The fact that it is often better for nation states to surrender sovereignty does not mean that they have no choice. Countries can try to be autarkic, like Albania did, but the costs are very high.

To be a major power, it is necessary to benefit from a strong economy, to master progress in communication and in energy, to take advantage of a State very capable of projecting a real diplomatic policy, of having a reliable currency of spare instrument and international deals, of being able to act outside its own borders to insure the transfer of the vital resources (water, petroleum or networks), to possess a nuclear strategic force and to have a universal enough cultural life to establish a force of attraction. The probability of an armed conflict is often taken into account in the economic decisions.

Nations remain very important. The vast bulk of economic production and activity takes place within nation states. The vast bulk of nation states provide at least the minimal law and order and infrastructure that is required for economic activity to proceed. There are international institutions, but their effectiveness depends on the willingness of the nation states to support their activities. However, people who go to international economic negotiations are not the same people who go to international security negotiations. The people who go to the World Trade Organisation meetings are not the same as the people who go to the meetings of the Wassenaar Arrangement. Similarly, the people who go to the UN and NATO are not the same as the people who go to meetings of the World Bank and IMF. This separate tracking can be good in that it insulates the spheres, countries can be in dispute in one sphere and 
cooperating in another, but there is a danger of actions in one sphere having unintended consequences in another.

For Machiavelli, laws and arms constitute the main foundations of States. In this situation, the military force may be perceived as a necessary and not sufficient condition for the national economic development. Today, the military actions are privileged, neither but nor for predation objectives. With the economic international dependence, the superpowers understand that without the threat of the use of their weapons, they are dependent of all states that are in situation of force for a special strategic production or resources.

"Globalization and universality are not going together; instead they are exclusive one and the other. Globalization regards technologies, markets, tourism or information. Universality concerns values, human rights, liberties, culture, and democracy. Globalization seems to be irreversible, the universal is dying out." (Baudrillard 1996).

\section{REFERENCES}

Baudrillard, Jean. 1996. "Le mondial et l'universel." Libération. March $18^{\text {th }}$.

Coulomb, Fanny. 2004. Economic theories of peace and war, London, New York: Routledge.

Dixit, Avinash. (2004) Lawlessness and Economics, Alternative Models of Governance. Princeton University Press.

Diamond, Jared, M. (1998) Guns Germs and Steel: a short history of everybody for the last 13,000 years. Vintage.

Dunne, Paul, Maria Garcia-Alonso Paul Levine and Ron Smith. 2006. "Managing Asymmetric Conflict." Oxford Economic Papers 58: 183-208.

Dunne, Paul, Maria Garcia-Alonso Paul Levine and Ron Smith. 2007. "Determining the Defence Industrial Base." Defence and Peace Economics, forthcoming.

Dunne, Paul, Ron Smith and Dirk Willenbockel. 2005. "Models of Military Expenditure and Growth: A Critical Review." Defence and Peace Economics 16(6) 449-462.

Dunne, Paul, and Ron Smith. 2007. "The Econometrics of Military Arms Races", in Handbook of Defense Economics 2: Defense in a Globalized World, ed. Sandler Todd and Hartley Keith. Forthcoming.

Carcia-Alonso, Maria and Ron Smith. 2006. "The Economics of Arms Exports Controls chapter 2 of Daniel H Joyner." The Future of Multilateral Nonproliferation Export Controls. Ashgate. pp. 29-45.

Fontanel, Jacques. 2002. Globalisation économique et sécurité internationale. Coll. Côté Cours. Avant-Propos de Kenneth Arrow. Grenoble: Université Pierre Mendes France.

Fontanel, Jacques. 2005. La globalisation en analyse. Géoéconomie et stratégie des acteurs, Collection "La Librairie des Humanités", Paris: L'Harmattan.

Fontanel, Jacques. 2007. Le concept de sécurité et l'économie, in "La securité internationale entre rupture et continuité, Mélanges en l'honneur du professeur Jean-François Guilhaudis, Bruxelles: Bruylant.

Hirshleifer, Jack. 2001. The Dark Side of the Force, Economic Foundations of Conflict Theory, Cambridge: University Press.

Kennedy, Paul. 1988. The Rise and Fall of the Great Powers: Economic Change and Military Conflict from 1500 to 2000. Unwin Hyman. 
INTERNATIONAL SECURITY, DEFENCE ECONOMICS AND THE POWERS OF NATIONS

Melman, Seymour. 1974. The permanent war economy, American capitalism in decline, Simon and Schuster. New York.

Seabright, Paul. 2004. The Company of Strangers, A Natural History of Economic Life. Princeton.

Schelling, Thomas C. 2006. An Astonishing Sixty Years: The Legacy of Hiroshima. American Economic Review 96(4): 929-937. September.

Smith, Ron P. 1995. The demand for military expenditure, in Handbook of Defence Economics Vol 1, ed. Hartley Keith and Sandler Todd, North Holland. 